\title{
Generating a Systematic Construction Accident Costs Calculation for Urban Rail Infrastructure Project
}

\author{
Izatul Farrita Mohd Kamar ${ }^{1}$, Asmalia Che Ahmad ${ }^{2}$, Mohmad Mohd Derus ${ }^{3}$, Mohd \\ Yusof Kasiron ${ }^{4}$, Nik Nur Khairunnisa Nik Mohd Ainul Azman ${ }^{5}$ \\ ${ }^{1}$ Centre of Postgraduate Studies, Universiti Teknologi MARA, Seri Iskandar Campus, Seri \\ Iskandar, 32610, Perak, Malaysia. \\ ${ }^{2,3,5}$ Faculty of Architecture Planning and Surveying, Universiti Teknologi MARA, Seri Iskandar \\ Campus, Seri Iskandar, 32610, Perak,Malaysia. \\ ${ }^{4}$ Mass Rapid Transit Corporation Sdn Bhd, Jalan Dungun, Bukit Damansara, 50490 Kuala \\ Lumpur, Malaysia.
}

izatu739@perak.uitm.edu.my' ${ }^{1}$,asmalia809@perak.uitm.edu.my²,moham266@perak.uitm.edu. $m y^{3}$, mohdyusof.kasiron@mymrt.com.my ${ }^{4}$, nickynisa93@yahoo.com ${ }^{5}$

Received: 13 July2018 Final Version Received: 22 August 2019

\begin{abstract}
Construction activities involve various risks, which can cause fatal major and minor accidents. The construction of Mass Rapid Transit (MRT), which is the most prestige urban rail infrastructure project in Malaysia, also exposed to those accidents. Both fatal and non-fatal accidents have high significance in economic burden to the MRT project stakeholders. However, it is very difficult to quantify the costs of these accidents. The objective of this study is to explore a method to calculate accident costs during the construction of urban rail infrastructure projects. To derive accident costs at construction sites, an accurate structure of the data collection system is very essential. This study is based on previous research that classifies the accident costs into two basic categories, which are direct costs and indirect costs. Measuring accident costs and providing the most specific variables are crucial as the calculations should be as detailed as possible for the accurate provision of project budget as well as cost for controlling and monitoring purposes. This study can also increase awareness of accident costs in urban rail infrastructure projects.
\end{abstract}

Keywords: Calculation Method, Accident Costs, Construction, Urban Rail Infrastructure project.

\section{INTRODUCTION}

Nowadays, the transportation industry infrastructure is rapidly moving towards a modern service. High speed rail (HSR) systems are already operationalised in many countries, such as Japan, England, Italy, Germany and France. Furthermore, the development of the whole European HSR network is planned. In this European context, the Commission of the European Communities (CEC) is aimed at standardising the HSR projects and concerned on safety issues (Diamantidis, Zuccarelli \& Westhäuser, 2000).

In Malaysia, the operational of the urban rail transport project construction started in 2002 for Light Rapid Transport (LRT) and Kuala Lumpur (KL) Monorail services. This construction was managed by Syarikat Prasarana Negara Berhad, which focuses on major Malaysian public transport infrastructure projects. This project is forever expanding over time to increase and participate the urban public transportation services demand; one of the National Key Result Areas, which is a priority under the Government Transformation Programme.

Recently, Malaysia has made another excel in the urban rail infrastructure with the completion of the Mass Rapid Transit (MRT) 1 line from Sungai Buloh to Kajang in July 2017. Other rail infrastructure projects which are currently in construction progress are the MRT 2 line, from Serdang to Putrajaya, Light Rail Transit (LRT) 3 line and LRT Bandar Utama to Klang line. These developments indicate that Malaysia is in line with other developed countries that have highspeed and modern public transportation. 
On 15 December, 2016, Malaysia and Singapore have signed a consensual agreement to develop the jointly $350 \mathrm{~km}$ HSR project. This project will reduce the travelling time between the two cities from 2 hours to approximately 90 minutes. The HSR serves as an alternative mode for public transport travel between Kuala Lumpur and Singapore. Then, in the 2017 Budget, the Malaysian Prime Minister announced the government's intention to build the East Coast Rail Project (ECRL). ECRL is identified as a high impact infrastructure project that will form the backbone of ECER's multimodal transport infrastructure. ECRL will connect many rural townships and is part of a larger plan to connect rural areas (Yong, 2017). These rail infrastructure projects will complement the existing road/expressway infrastructure of the Lebuhraya Pantai Timur and the existing KTMB East Coast Line and ports.

With this rail infrastructure project rapid development, fatalities, serious injuries and damage to properties at recent project sites will occur each year. Opposing from small and medium-sized construction projects, majority of infrastructure projects frequently comprise a diversity of different tasks and features (Shiferaw et al., 2012). Due to the unique site conditions, delay, budget overruns (Kean, 2011) and hidden transaction costs have arose (Sha, 2011). In addition, the possibility of increase in accidents for this huge project is more than other types of construction, due to many numbers of workers, large amount of plants and equipment, a lot of materials used, complicated in operations and complex activities at site (Guo et al., 2013).

\section{THEORETICAL BACKGROUND}

The study of accident costs was discussed for centuries, where Heinrich (1931) had pioneered in this field for more than 80 years ago. Numerous studies (Heinrich, 1959; Michaud, 1995; Neville, 1998; Monnery, 1999; Dorman, 2000; LaBelle, 2000; Siegel \& Shim, 2000; Corcoran, 2002; Goestsch, 2013; Asan, n.d.; Pellicer et al., 2014; Feng et a., 2015) have summarised that the actual accident costs for the company are more higher than the direct costs or insurable costs. Issues in developing a construction accident model are the accuracy in evaluating of the indirect costs. However, the direct costs, such as hospital cost, medical treatment cost and compensation cost, are usually directly priced and insured besides being monitored ((Jallon et al., 2011).
Most construction companies and stakeholders do not systematically calculate both direct and indirect costs of accident, due to the lack of knowledge and information regarding on the compensation mechanisms involved when accidents occurred (Gavious et al., 2009). In project practice, clients, consultants and contractors have the tendency to ignore the cost of an accident, without realising the greatness of its impacts to the organisation, industry and country. This is particularly true, especially for the government projects, because of the government policies that require all projects must be insured. Most stakeholders have confidence in that most construction related items are insured and therefore there are not necessary to calculate these accident costs, which require large data collection.

Moreover, the shared economic approach in estimating benefits of safety investment assumes that accidents as undesired side effects, whereas these accident costs are assumed to be a sank costs (Oi, 1974; Thaler \& Rosen, 1975). Based on this approach, a detailed safety cost from the consultants or the clients is often excluded from a contract amount. This exclusion is critical to ensure the project profitability.

Another reasons for the marginalisation of workplace accident costs by construction stakeholders consist of the difficulties in measuring, full burden work carried out by the managers, biased accounting methods and lack of quality in the safety departments (Dorman, 2000). In addition, Feng et al., (2014) and Jallon et al., (2011) revealed the quantification, evaluation and identification of many of the losses incurred in an accident are difficult as they are "hidden" costs. These "hidden" costs may be having the most significant costs incurred from that accident. They are often difficult to calculate due to complication in applying the existing models.

It is quite stressful in applying models to examine and estimate prevention costs in the construction industry. This is because, many of the research focused in the manufacturing sector, while the traditional cost models for analysing these costs are limited to recognizing and organising them. López et al., (2013) believed that the models should be 'tailor made' to each company according to conditions.

Previous studies revealed that there are a several safety and health cost models from other countries, such as United Kingdom (Health and Safety Executive, 2014), Singapore (Workplace Safety and Health Institute, 2013), Australia 
(Safe Work Australia, 2015) and Malaysia (KLIACS JKKP, 2013). However, there is no study done that emphasis on the investigation of accident costs which incurred during the construction of urban rail infrastructure projects, specifically in a developing country such as Malaysia. This significant gap that is highlighted in this study is towards the development of safety cost models related with current rail infrastructure transportation trends in the country.

The objective of this study is to explore methods to calculate accident costs in the construction of urban rail infrastructure projects. The reliable evaluation of the accident costs can assist employers and workers to overcome the narrow routine economic approach adopted by them. Moreover, it also can help them to allocate the suitable items that require investment in safety measures in the strategic safety investment plan.

\section{CALCUlation OF ACCIDENT COST APPROACHES}

Accident costs are usually calculated with much uncertainty. Among the several sources of uncertainty in the calculation is in determining the right component of the costs. Several approaches by using formula calculations were proposed for quantifying the actual total cost of an accident. Table 1 shows several accident costs that were formulated by previous researchers.

Table 1: Accident Costs Formula Approaches from previous researchers.

\begin{tabular}{|c|c|}
\hline Researcher & Formula of Accident Costs \\
\hline $\begin{array}{l}\text { Aaltonen et } \\
\text { al., (1996) }\end{array}$ & $\begin{array}{l}\text { Total Costs }=\text { Individual Costs }+ \\
\text { Company Costs }+ \text { National Economy } \\
\text { The Accident Consequence Tree (ACT) } \\
\text { Method was developed based on the fault } \\
\text { tree method for calculating accident } \\
\text { costs. }\end{array}$ \\
\hline $\begin{array}{c}\text { Hammer \& } \\
\text { Price } \\
(2001)\end{array}$ & $\begin{array}{l}\text { Total Cost }=\text { Accident Prevention Costs }+ \\
\text { Legal Costs + } \\
\text { Immeasurable Costs + } \\
\text { Immediate Losses + } \\
\text { Insurance Costs + } \\
\text { Other Safety Costs + } \\
\text { Rehabilitation Cost }+ \\
\text { Welfare Cost }\end{array}$ \\
\hline Wong (2008) & $\begin{array}{l}\text { Social Cost = Daily Wage } \mathrm{x} 365 \text { days } \mathrm{x} \\
\text { (retire age } 65- \\
\text { injury age) } \mathrm{x} \% \\
\text { disability/100 }\end{array}$ \\
\hline
\end{tabular}

\begin{tabular}{|c|c|}
\hline & $\begin{array}{l}\text { Social Cost = Daily Wage x } 365 \text { days } x \\
\text { (retire age } 65 \text { - death age) }\end{array}$ \\
\hline $\begin{array}{l}\text { Gavious et } \\
\text { al., (2009) }\end{array}$ & $\begin{array}{l}\text { Total Cost = Cdirect }+ \text { Cindirect }+ \\
\text { Cpayment }+ \text { Cimmeasurable } \\
\text { Where, the parameters that reflect the } \\
\text { direct costs, indirect costs, payment costs } \\
\text { and immeasurable costs are formulated } \\
\text { as: } \\
\text { Cdirect = Cdamage }+ \text { Cmedical }+ \text { Cfine } \\
+ \text { Cinsurance } \\
\text { Cindirect = Ccapacity lost }+ \text { Cschedule }+ \\
\text { Crecruit }+ \text { Cwork time }+ \\
\text { Cwip }+ \text { Cmang } \\
\text { Cpayment }=\text { M (PaynewW }) \sum_{i=e}^{W 2} \text { Bi }- \\
\text { NI x W } 2 \\
\text { Cimmeasurable }=\text { Creputation }+ \text { Cmorale }\end{array}$ \\
\hline $\begin{array}{l}\text { KLIACS } \\
\text { JKKP } \\
(2013)\end{array}$ & $\begin{array}{l}\text { Total Cost = individual cost + employer } \\
\text { cost }+ \text { stakeholder cost } \\
\text { Where, } \\
\text { Individual cost = immediate loss of } \\
\text { earnings }+ \text { loss of future earnings }+ \\
\text { permanent afflictions }+ \text { health and } \\
\text { rehabilitation costs + administrative costs } \\
+ \text { finding a new occupation costs }+ \text { Costs } \\
\text { of housewives' work and relatives' work } \\
\text { to take care of the injured workers }\end{array}$ \\
\hline $\begin{array}{l}\text { KLIACS } \\
\text { JKKP } \\
(2013)\end{array}$ & $\begin{array}{l}\text { Employer cost }=\text { Damage Cost }+ \\
\text { Medical Cost }+ \text { Fine Cost }+ \\
\text { Insurance Costs }+ \text { Search and } \\
\text { Rescue Costs }+ \text { Capacity Lost }+ \\
\text { Schedule Cost }+ \text { Recruiting Cost }+ \\
\text { Work Time Cost }+ \text { Work in Progress } \\
\text { Cost + Management Cost }+ \text { External } \\
\text { Investigation Cost }+ \text { Accident } \\
\text { Report Cost }+ \text { Payment Cost }+ \\
\text { Immeasurable Cost } \\
\text { Stakeholder cost }=\text { Government cost } \\
+ \text { Consultants cost }+ \text { Clients cost }\end{array}$ \\
\hline $\begin{array}{l}\text { Health and } \\
\text { Safety } \\
\text { Executive } \\
(2014)\end{array}$ & $\begin{array}{l}\text { Total Cost = Individual Cost + Employer } \\
\text { Cost }+ \text { Government Cost } \\
\text { Where, } \\
\text { Individual cost = Loss of Income + } \\
\text { Compensation Payments }+ \text { Health and } \\
\text { Rehabilitation Costs }+ \text { Administrative } \\
\text { Costs + Non-Financial Costs. } \\
\text { Employer cost = Sick Pay Payments + } \\
\text { Insurance Premiums + Production } \\
\text { Disturbance Costs }+ \text { Administrative and } \\
\text { Legal Costs. } \\
\text { Government cost = Costs arising from } \\
\text { loss of earnings to the individual (benefits } \\
\text { payments, reduction in tax and national } \\
\text { insurance receipts) + Medical Treatment } \\
\text { Costs and Rehabilitation Costs + } \\
\text { Administration and Legal Costs }\end{array}$ \\
\hline $\begin{array}{l}\text { Pellicer et } \\
\text { al., (2014) }\end{array}$ & $\begin{aligned} \mathrm{CC}= & {[0.0745 * \mathrm{BS}]+\left[\beta^{*} \mathrm{BC}\right]+} \\
& {\left[\mathrm{EX}^{*} \mathrm{NH}^{* 10-}\right.} \\
& \left.6 * \Sigma_{\mathrm{jk}} \mathrm{NA}_{\mathrm{jk}} * \mathrm{CT}_{\mathrm{jk}}\right]\end{aligned}$ \\
\hline
\end{tabular}




\begin{tabular}{|c|c|}
\hline & $\begin{array}{l}\qquad\left[0.75 * \mathrm{GS}^{*} \mathrm{EX}^{*} \mathrm{NH}^{* 10-}\right. \\
\left.\qquad 6 * \sum_{\mathrm{jk}}\left(\mathrm{DL}_{\mathrm{jk}}-1\right) * \mathrm{NA}_{\mathrm{jk}}\right] \\
\text { Where, } \\
\mathrm{CC}=\text { Total Expected Cost of } \\
\text { occupational accidents } \\
\mathrm{BS}=\text { Base Salary } \\
\beta=\text { Ratio of safety budget invested in the } \\
\text { prevention cost } \\
\mathrm{BC}=\text { Budget of the construction project } \\
\mathrm{EX}=\text { Exposure time at the construction } \\
\text { site FI } \\
\mathrm{NH}=\text { Number of man-hours per million } \\
\text { hours worked for the entire } \\
\text { Spanish construction industry }\end{array}$ \\
\hline $\begin{array}{l}\text { Pellicer et } \\
\text { al., (2014) }\end{array}$ & $\begin{array}{l}\text { NA }=\text { Number of accidents for the entire } \\
\quad \text { Spanish construction industry } \\
\text { CT }=\text { Cost of the accident per type } \\
\text { GS }=\text { Daily gross salary } \\
\text { DL }=\text { Days of medical leave } \\
j \text { = accident type } k \text { = severity of the } \\
\text { accident }\end{array}$ \\
\hline
\end{tabular}

Aaltonen et al., (1996) developed the Accident Consequence Tree (ACT) Method, which is based on the fault tree method for calculating the accident costs. The consequences of the accident to the injured worker, the company and the national economy were identified with the aid of the consequence tree. The ACT Method was applied to workplace accidents in 18 Finnish furniture factories of different sizes and product types.

On the other hand, the accident costs which were formulated by Hammer \& Price (2001)were more general, not specific to any groups to whom the cost incurred. The accident costs were not classified into direct costs and indirect costs, which are commonly recommended by other researchers.

Wong (2008) developed the accident costs formula from the society point of view. Social costs are defined as any item that will result in the utilisation of national resources. These costs incurred for workers injury and fatal were separately formulated due to different accident severity. In addition, Tang (1997) revealed that the costs incurred by society are in broader perspective and the costs are higher than costs incurred by the contractors.

Gavious et al., (2009) proposed the reliable methods in estimating the costs incurred for an accident in the industrial sector, especially in relation to loss of production. The costs contained two main cost categories, which are direct costs and indirect costs. Researchers had considered all parameters that affect costs when an accident occurred, which are from the direct costs, indirect costs, payment costs and immeasurable costs.
Nevertheless, the study from KLIACS_JKKP (2013) in Malaysia, described that the formula for total cost associated with workplace injuries is made out by the three distinct groups to whom the cost falls, namely the accident victims, the victims employers and other stakeholders. This combination contributes to improving the ease of data collection and the quantity and quality of data collected. The stakeholders are responsible during the design stage of the construction. The client needs to invest for each safety prevention cost components that stated in the bill of quantities. They also need to bear the consultant's fee based on certain charges. The relevant stakeholder, when accident occurred is the government. The government needs to pay the compensation cost to the victim. Combining the costs of these three groups gives the total cost as a whole.

The Health and Safety Executive (2014) took a different approach. The formula for workplace injuries costs in Great Britain is by combining the costs from different three groups, which are individual's costs, employer costs and government costs. The actual total costs will be summarised from these groups, who borne the costs of accident.

While, Pellicer et al., (2014) developed a mathematical model as a method that would permit employers for computing the estimation for each cost category. This estimate should be applied during the construction project design phase and execution phase at the work site. However, the model still has a few limitations.

Determining a reliable correlation between prevention costs and accidents occurred at the site is difficult. Many case studies are required to gain the reliable data to suggest such a link and this correlation must be confirmed by other data. Moreover, in its current form, the model was not specific to any project type or defines project characteristics.

In short, the literature highlights the existing accident cost formulas across the globe, but their relations to the study environment for the rail infrastructure projects are limited. Diffusion of a new cost formula could provide valuable information for future estimation when accident occurred at the MRT and LRT sites.

In order to develop a systematic accident costs calculation for urban rail infrastructure projects, all existing formulas that were developed by previous researchers were considered. By doing so, the understanding of whether the existing 
formula is relevant or not is used when the accident which happened were identified.

Therefore, the formula for total cost related to workplace injuries in this research is divided into employer cost, victim cost and stakeholder cost. The employer cost is further divided into two, which are direct cost and indirect cost. Direct cost is the cost that is accrued directly from the accident. The costs are typically covered by Social Security Organisation (SOCSO) and insurance company. While indirect cost is the cost item that is not covered by the worker's compensation insurance.

For the victim cost, the costs were incurred by the victim when accident happened. Usually, the cost items incurred by the victim are from the indirect costs, where it is uninsurable cost. Stakeholders cost is usually the compensation cost paid by the government agencies to the victim. This combination contributes to improving the ease of data collection and quantity and quality of data collected.

The total accident cost equation was adapted by KLIACS JKKP (2013), is given as:

Total Accident Cost $=$ Employer Cost + Victim Cost + Stakeholders Cost

Where,

Employer Cost $=$ Direct Cost + Indirect Cost

The total direct accident cost equation is given as:

Direct Cost $=$ Medical Treatment Cost + Hospital Cost + Damage/Repair Cost + Fine Cost

Where,

Medical Treatment Cost - Immediate medical treatment costs. This cost includes medical equipment used when the accident happened, including the cost to refill, payment to person who arranges for emergency services and transport to the hospital and the salary of first aider.

Hospital Cost - This cost includes transportation cost to hospital, the hospitalisation costs which includes the hospital bills, payment for person who escort the victim to the hospital, payment for the person who visits the victim at the hospital and cost of follow up treatment after the victim is admitted from the hospital.
Damage/Repair Cost - The damage to machinery, material and equipment. Commonly, an accident not only involves injuries, but also comprises the damage to machinery, material and equipment. This damage can be total lost or can be repaired. The repair cost includes salary of labour to repair and cost of spare part. The cost of cleaning to ensure the site area back to operational working is also counted in this cost component.

Fine Cost - If an accident is caused due to violations of safety procedures or even breaking the law, the company may be exposed to fines by a court or by the local authorities likes DOSH.

While, the total indirect accident cost equation is given as:

Indirect Cost $=$ Accident Report Cost + Replacement Cost + Legal and Administration Cost + Schedule Cost + Productivity Cost + Work in Progress Cost + Compensation to Victim Cost + Uninsured Medical Cost + Management Cost + Prevention Cost

Where,

Accident Report Cost - This includes the costs of printing, binding and photocopy when preparing the accident report.

Replacement Cost - The cost includes hiring training for new worker, who replaced the injured ones.

Legal and Administration Cost - Consists of legal proceeding cost and the cost of administrative works to prepare the report, such as the salary and the time cost to prepare the report, including recordkeeping and filling works.

Schedule Cost - When an accident happened, a slowdown in production will affect the timetable schedule. The solution that the company will create by rescheduling the work programme. The cost to reproduce new schedule and coordinating it is accounted in this cost component.

Productivity Loss Cost - This cost component consists of capacity loss (slowdown in production, machinery and equipment idling), time lost (time lost by injured and other workers, extra hours employed for overtime) and reduced productivity due to injured worker absence for several days, including the day to follow up treatment. 
Work in Progress Cost - Consists of the cost of recovering works and investigation tools. The recovering works include the cost of additional inventory and recovering works.

Compensation to Victim Cost - The amount of money that the employer has to spend for the victim. These costs include the cost to send back victim's body to his country, the costs of escort staffs, including their transportation, accommodation and all expenses during their task and the ex gratia payment to the victim's family.

Uninsured Medical Cost - Usually this cost component relates to the traditional treatment like massage for the injured body.

Management Cost - Consists the cost of health, safety and environment committees to investigate the accident occurred. This cost includes their salary on doing the investigation, meeting and interviews with the victim and other workers.

Prevention Cost - This cost component consists of ad hoc safety training for corrective action. The costs consist of training fee (trainer cost including any equipment used during the training), transportation cost and lodging cost during the training period.

For the victim cost equation is given as:

Victim Cost $=$ Take Care Cost + Unpaid Leave Salary

Where,

Take Care Cost - This includes the costs of 'housewives work' or 'relatives work' to take care of injured worker, and the unpaid leave salary had to bear by the injured worker during his medical leave.

The total other stakeholders cost equation is given as:

Stakeholders Cost $=$ Labour Department + CIDB + SOCSO + Insurance Company

The stakeholder's cost - The compensation costs paid by the government agencies to the victim. For the local workers, they can have claimed from the Construction Industry Development Board (CIDB), Social Security Organisation (SOCSO) and Insurance Company if an accident happened to them. While for foreign workers, they can claim from the Labour Department
(JTK), CIDB and Insurance Company when an accident occurred.

\section{SIMULATION OF COST ACCIDENT CALCULATION}

In this section, the cost of accident was simulated to prove the viability of the generated calculation formula. The accident cost uses real data taken from one of the accident cases of MRT 1 Project. The MRT 1 Project begins from Sungai Buloh and runs through the city centre of Kuala Lumpur of before ending in Kajang. The construction of the first line commenced in July 2011 and it was start operation on 16 Dec 2016. There are 31 stations, with $51 \mathrm{~km}$ line involved for the first MRT line Project. Six types of packages in the MRT 1 project, namely viaduct/guideway package, underground, advance, system, bus depot and depot. Since the types of work for each package in the MRT 1 construction varies, the work packages contractors (WPC) from viaduct (guideway) package were selected as a sample of the study. The reason being that the viaduct (guideway) package is the main package for the MRT 1 project, where it also covers the construction of stations.

There are 8 WPC (viaduct/guideway) in MRT 1 Project. The data was presented in the following table based on an accident occurred during the construction of the MRT 1 Project for viaduct (guideway) package which had caused injury to one foreign worker working as a labourer. The data were collected from the past accident records and accident reporting documents.

Emergency Response Vehicle evacuated the injured worker to the nearest hospital. This accident was classified under Class 2 (LTI resulting in permanent disability) accident. The victim was admitted in the hospital for seven (7) days. Later, the victim obtained a medical leave for thirty (30) days due to his injury. In those four (4) weeks, the company did not recruited an outsourcing worker. The co-workers replaced the injured worker to carry out the works at site.

To investigate the accident, the Health, Safety \& Environment (HSE) team members, which consists of managers, safety personnel (safety manager, safety officer, site safety supervisor) and site supervisor were appointed to participate. The investigation was a dedicated one (1) to two (2) working days, and after information was gathered from witnesses, the safety personnel will prepare the initial accident report. 
4.1 EMPLOYER COST (DIRECT COST)

Direct cost $=$ RM120 + RM6,770 + RM5,000 + RM20,000 = RM11,890

Table 2: The direct cost for employer.

\begin{tabular}{|c|c|c|}
\hline Parameter & $\begin{array}{l}\text { Value } \\
\text { (RM) }\end{array}$ & Remarks \\
\hline $\begin{array}{l}\text { Medical Treatmer } \\
\text { Cost }\end{array}$ & 120 & $\begin{array}{l}\text { RM120 salary of first aider } \\
\text { per day or other person to } \\
\text { arrange for emergency } \\
\text { services and transport. }\end{array}$ \\
\hline Hospital Cost & 6,770 & $\begin{array}{l}\text { RM50 fuel transportation } \\
\text { cost }+ \text { RM6,050 medical } \\
\text { cost at hospital (RM2,000 } \\
\text { admission fee, RM150 x } 7 \\
\text { days for operation fee \& } \\
\text { RM3,000 for major } \\
\text { surgery fee) + RM160 } \\
\text { salary of staff who escort } \\
\text { victim to hospital + } \\
\text { RM160 salary of staff visit } \\
\text { at the hospital + RM350 } \\
\text { follow up treatment fee. }\end{array}$ \\
\hline $\begin{array}{l}\text { Damage/Repair } \\
\text { Cost }\end{array}$ & 5,000 & $\begin{array}{l}\text { The damage to the } \\
\text { materials, equipment and } \\
\text { machines. }\end{array}$ \\
\hline Fine Cost & 20,000 & Fine by authority (DOSH) \\
\hline
\end{tabular}

\subsection{EMPLOYER COST (INDIRECT COST)}

Indirect cost $=\mathrm{RM} 120+\mathrm{RM} 2,800+\mathrm{RM} 3,000$

$+\mathrm{RM} 1,120+\mathrm{RM} 8,152+5,000=\mathrm{RM} 31,840$

Table 3: The indirect cost for employer.

\begin{tabular}{|c|c|c|}
\hline Parameter & $\begin{array}{l}\text { Value } \\
\text { (RM) }\end{array}$ & Remarks \\
\hline Accident & 120 & RM15 (printing and binding \\
\hline Report & & of report) $\times 8$ copies for \\
\hline Cost & & $\begin{array}{l}\text { Client, PDP, DOSH, } \\
\text { Insurance Company \& } \\
\text { Safety Department. }\end{array}$ \\
\hline $\begin{array}{l}\text { Replacement } \\
\text { Cost }\end{array}$ & - & $\begin{array}{l}\text { Usually, there is no } \\
\text { replacement of new } \\
\text { workers. Other workers will } \\
\text { cover the jobs that is carried } \\
\text { out by the victim. }\end{array}$ \\
\hline $\begin{array}{l}\text { Legal and } \\
\text { Administration } \\
\text { Cost }\end{array}$ & 2,800 & $\begin{array}{lr}\text { RM300 salary of safety } \\
\text { personnel (day) + RM100 } \\
\text { salary } \\
\text { safety/administrative } & \text { of } \\
\end{array}$ \\
\hline & & $\begin{array}{lcc}x & 7 & \text { days }\end{array}$ \\
\hline Schedule Cost & 3,000 & $\begin{array}{l}\text { Cost to reproduce new } \\
\text { schedule due to the } \\
\text { accident. } \\
\text { proposed new traffic plan } \\
\text { management plan, where it } \\
\text { involved the cost to certify } \\
\text { the drawing. }\end{array}$ \\
\hline $\begin{array}{l}\text { Productivity } \\
\text { Loss Cost }\end{array}$ & 1,120 & $\begin{array}{l}\text { RM640 time lost by other } \\
\text { workers because of the } \\
\text { accident }+ \text { RM } 400 \text { extra } \\
\text { hours employed to recover } \\
\text { production + RM } 80 \text { lost } \\
\text { productivity due to follow }\end{array}$ \\
\hline
\end{tabular}

Work in
Progress Cost

up treatment (victim salary/day). Cost that are needed to replace the injured worker (it depends on the policy of the company if there are recruiting new workers or letting the co-worker to work extra hours).

Compensation - - The amount of money that to Victim Cost the employer had to spend for the victim. These costs included the cost to send back victim's body to his country, the costs of escort staffs including their transportation,

accommodation and all the expenses during their task and the ex gratia payment to the victim's family. Usually, this cost component will involve for the class 1 accident (fatality).

Uninsured - $\quad$ The victim only goes for the Medical Cost hospital treatment rather than traditional treatment such as massage treatment.

Management 8,152 Salary (per day) $\mathrm{x}$ time Cost spent estimated for the HSE committee members to do the investigation works (interviewing, attending meeting).

Prevention Cost 5,000 The costs consist of salary of workers who are attending the training $x$ number of days of training + training fee (trainer cost including any equipment used during the training) + transportation cost + lodging cost during the training period.

\subsection{VICTIM COST}

Victim cost $=$ RM2,400

Table 4: The indirect cost for victim.

\begin{tabular}{lcl}
\hline Parameter & $\begin{array}{l}\text { Value } \\
\text { (RM) }\end{array}$ & \multicolumn{1}{c}{ Remarks } \\
\hline $\begin{array}{l}\text { Take Care } \\
\text { Cost }\end{array}$ & $\begin{array}{l}\text { Majority of accidents } \\
\text { happened to the foreign } \\
\text { workers. No spouse of } \\
\text { relative taken care cost } \\
\text { to them. So, this cost } \\
\text { component was not }\end{array}$ \\
& RM2,400 & $\begin{array}{l}\text { calculated in the victim } \\
\text { cost. }\end{array}$ \\
& $\begin{array}{l}\text { This cost component } \\
\text { was incurred by the } \\
\text { foreign workers when } \\
\text { they cannot work at }\end{array}$ \\
Leave & site. The cost was \\
Salary & calculated based on the \\
Cost & & \\
& &
\end{tabular}


day) $\mathrm{x}$ days of unpaid leave. For this case, the victim's salary RM $80 \mathrm{x}$ 30 days of unpaid leave.

\subsection{STAKEHOLDERS COST}

Stakeholder cost $=\mathrm{RM} 13,287+\mathrm{RM} 3,289+$ RM30,400 = RM46,976

Table 5: The stakeholder cost.

\begin{tabular}{|c|c|c|}
\hline Parameter & $\begin{array}{l}\text { Value } \\
(\mathrm{RM})\end{array}$ & Remarks \\
\hline $\begin{array}{l}\text { Labour } \\
\text { Departmet }\end{array}$ & RM13,287 & $\begin{array}{l}\text { Majority } \\
\text { happened to the } \\
\text { foreign } \\
\text { Labour workers. } \\
\text { was considered to the } \\
\text { active and registered } \\
\text { foreign construction } \\
\text { workers. }\end{array}$ \\
\hline SOCSO & - & $\begin{array}{l}\text { This cost component } \\
\text { was contributed to the } \\
\text { local workers. The } \\
\text { compensation was paid } \\
\text { based on the medical }\end{array}$ \\
\hline CIDB & RM3,289 & $\begin{array}{l}\text { benefit, } \\
\text { temporary/permanent } \\
\text { disablement benefit } \\
\text { and funeral. } \\
\text { All personnel working } \\
\text { in construction sites }\end{array}$ \\
\hline $\begin{array}{l}\text { Insurance } \\
\text { Company }\end{array}$ & RM30,400 & $\begin{array}{l}\text { must obtain a green } \\
\text { card before entering } \\
\text { the construction site. } \\
\text { CIDB green card is } \\
\text { automatically covered } \\
\text { by a special insurance } \\
\text { scheme that insures the } \\
\text { construction personnel } \\
\text { against death and } \\
\text { accidents. } \\
\text { Workers' } \\
\text { compensation is a form } \\
\text { of insurance providing } \\
\text { wage replacement and } \\
\text { medical benefits to } \\
\text { employees injured. } \\
\text { MRT Corporation Sdn. } \\
\text { Bhd. as a client was } \\
\text { provided this insurance } \\
\text { for MRT project. }\end{array}$ \\
\hline
\end{tabular}

\subsection{TOTAL ACCIDENT COST}

Table 6: The total accident costs including employer cost, victim cost and stakeholder

\begin{tabular}{lccc}
\hline Parameter & $\begin{array}{c}\text { Value } \\
(\mathrm{RM})\end{array}$ & $\begin{array}{c}\text { Sub- } \\
\text { percentage } \\
(\%)\end{array}$ & $\begin{array}{c}\text { Percentage } \\
(\%)\end{array}$ \\
\hline $\begin{array}{l}\text { Employer } \\
\text { Cost }\end{array}$ & RM11,890 & 27.19 & \\
i) Direct Cost & & & \\
ii) Indirect Cost & RM31,840 & 72.81 & \\
Total & RM43,730 & - & 46.97 \\
Employer & & & \\
Cost & & &
\end{tabular}

\begin{tabular}{lccc} 
Victim Cost & RM2,400 & - & 2.58 \\
$\begin{array}{l}\text { Stakeholder } \\
\text { Cost }\end{array}$ & RM46,976 & - & 50.45 \\
\hline & & & \\
$\begin{array}{l}\text { Total Accident } \\
\text { Cost }\end{array}$ & $\mathbf{R M 9 3 , 1 0 6}$ & & $\mathbf{1 0 0 . 0 0}$ \\
\hline
\end{tabular}

The total accident cost for the above case was estimated around RM93,106. Even in a small accident case, the indirect cost weights $72.81 \%$. The result showed that the indirect costs were 3.73 times larger than the direct ones, yet most companies do not regularly calculate these costs. This finding further reinforced the notion that the costs of an accident incurred by the employee are related to previous studies. The Heinrich`s ratio of (1:4) between direct and indirect accident costs has frequently used in previous studies on safety-related literature (Manuele, 2011).

In contrast to previous studies by Pillay and Haupt (2008), revealed that the accident cost ratio for non-fatalities is higher (i.e. 1:1.6). While the latest study from (Nur et al., 2019), found that for the permanent disability accident cases, it showed that the total direct cost and indirect cost is RM 21,668.00 and RM 42,439.00, respectively, which made up a ratio of 1:1.94. As discuss by Teo and Feng (2011) stated that there is no generally accepted ratio of direct to indirect costs. OSHA (2007) suggest that in construction industry the ratio of direct costs to indirect cost ranges from as low as 1:1.0 to as high as 1:20.0. Whereas, Choi (2006) proposed that the accident costs ratio of injuries may range from 1:2.0 to 1:20.0. Hence, the accident cost ratio is not necessarily fixed. The total accident costs incurred by this company were lost much more money than was expected.

\section{CONCLUSION}

This paper provides a cost estimation method to calculate accident costs in the construction of urban rail infrastructure projects in Malaysia. It is based on a theoretical approach that classifies these costs in two categories i.e. direct and indirect costs based on the different cost bearers, who are employer, victim and stakeholder. A method of estimating the cost components for each category is proposed even though there are a few other approaches of a model that formulates accident costs. It provides a mathematical formulation for the calculation of the different types of costs component that intervene in the accident cases.

This generation of systematic calculation of accident costs was significantly designed for the construction projects of urban rail infrastructure. 
This formula could heighten the importance about the effect of an accident to the employer's company economic and budgeting. In addition, it could enrich awareness in improving preventive measures for a construction project. A reliable evaluation of the cost of accidents for the construction of urban rail infrastructure projects could help work packages contractors (WPC) to plan the investment in safety measures appropriately according to the related accident cost components. Most significantly, this formula could provide valuable information for the future estimation of accident costs occurred for incoming rail infrastructure project in Malaysia, such as HSR, ECRL, MRT2, MRT3 and LRT3.

\section{ACKNOWLEDGEMENTS}

The authors gratefully acknowledge the Centre of Postgraduate Studies, Universiti Teknologi MARA, Seri Iskandar Campus, Seri Iskandar, for supporting this research study. The research study described in this paper is also supported by the Fundamental Research Grant Scheme (FRGS) under the Malaysian Ministry of Higher Education (MOHE). Project code: FRGS/1/2016/SSI11/UITM/03/1. Special gratitude is also given to the MRT Corporation Sdn. Bhd. for approving data and goes to the industrial practitioners for their kind cooperation and generous contributions to the development of this research.

\section{REFERENCES}

Aaltonen, M. V. P., Uusi-Rauva, E., Saari, J., Antti-Poika, M., Räsänen, T., \& Vinni, K. (1996). The accident consequence tree method and its application by real-time data collection in the Finnish furniture industry. Safety Science, 23(1), 11-26. https://doi.org/10.1016/09257535(96)00021-5

Asan, A. (n.d.). Developing an Accident Causation Model for Accident Prevention At Building Construction Sites.

Corcoran, D. (2002). The Value of Estimating the Hidden Costs of Accidents. Occupational Health and Safety, 71(9), 26-30.

Diamantidis, D., Zuccarelli, F., \& Westhäuser, A. (2000). Safety of long railway tunnels. Reliability Engineering and System Safety, 67(2), 135-145. https://doi.org/10.1016/S09518320(99)00059-9

Dorman, P. (2000). The Economics of Safety, Health, and Well-Being at Work: An
Overview. InFocus Program on

SafeWork, International Labour Organisation, The Evergreen State College, 1-41.

Feng, Y., Teo, E. A. L., Ling, F. Y. Y., \& Low, S. P. (2014). Exploring the interactive effects of safety investments, safety culture and project hazard on safety performance: An empirical analysis. International Journal of Project Management, 32(6), 932-943. https://doi.org/10.1016/j.ijproman.2013.1 0.016

Feng, Y., Zhang, S., \& Wu, P. (2015). Factors influencing workplace accident costs of building projects. Safety Science, 72, 97104. https://doi.org/10.1016/j.ssci.2014.08.008

Gavious, A., Mizrahi, S., Shani, Y., \& Minchuk, Y. (2009). The costs of industrial accidents for the organization: Developing methods and tools for evaluation and cost-benefit analysis of investment in safety. Journal of Loss Prevention in the Process Industries, 22(4), 434-438. https://doi.org/10.1016/j.jlp.2009.02.008

Goestsch, D. L. (2013). Construction Safety and Health (Second). New Jersey, USA: Pearson Education.

Guo, H. L., Li, H., \& Li, V. (2013). VP-based safety management in large-scale construction projects: A conceptual framework. Automation in Construction, 34 ,

16-24.

https://doi.org/10.1016/j.autcon.2012.10.0 13

Hammer, W., \& Price, D. (2001). Occupational Safety Management and Engineering (5th ed.). New Jersey: Prentice Hall.

Health and Safety Executive. (2014). Costs to Britain of workplace fatalities and selfreported injuries and ill health, 2014/15.

Heinrich, H. W. (1931). Industrial Accident Prevention. New York: McGraw-Hill.

Heinrich, H. W. (1959). Industrial Accident Prevention: A Scientific Approach (4th ed.). McGraw-Hill Books Company.

Jallon, R., Imbeau, D., \& De Marcellis-Warin, N. (2011). Development of an indirectcost calculation model suitable for workplace use. Journal of Safety Research, 42(3), 149-164. https://doi.org/10.1016/j.jsr.2011.05.006

Kean, J. R. (2011). Improving project predictability with the application of critical project governance structures. Association for the Advancement of Cost Engineering, AACE 2011, 2, 1023-1035.

KLIACS_JKKP. (2013). Kajian Mengenai Kos 
Kemalangan Di Tempat Kerja Bagi Sektor Pembinaan.

KLIACS _ JKKP 2013 Kajian Mengenai Kos Kemalangan Di Tempat Kerja Bagi Sektor Pembinaan. (2008), 1-77.

LaBelle, J. E. (2000). What do accidents truly costs? Determining total incident costs. Professional Safety, 45(4), 38-42.

López-Alonso, M., Ibarrondo-Dávila, M. P., Rubio-Gámez, M. C., \& Munoz, T. G. (2013). The impact of health and safety investment on construction company costs. Safety Science, 60, 151-159. https://doi.org/10.1016/j.ssci.2013.06.013

Manuele, F. A. (2011). Accident Costs Rethinking ratios of indirect to direct costs. Safety Management, (January), 3947.

Michaud, P. A. (1995). Accident Prevention and OSHA Compliance. CRC Press.

Monnery, N. (1999). The costs of accidents and work-related ill-health to a cheque clearing department of a financial services organisation. Safety Science, 31(1), 59-69. https://doi.org/https://doi.org/10.1016/S09 25-7535(98)00054-X

Neville, H. (1998). Workplace accidents: they cost more than you might think. Industrial Management, 40(1), 7-9.

Nur, N., Nik, K., Ainul, M., Ahmad, A. C., Derus, M. M., \& Mohd, I. F. (2019). Determination of Direct to Indirect Accident Cost Ratio for Railway Construction Project, 9.

Oi, W. Y. (1972). On the Economics of Industrial Safety. Law and Contemporary Problems.

OSHA, Safety and Health Management System e- Tool: Costs of Accident, United States Department of Labor, 2007. [Online]. Available:

https://www.osha.gov/SLTC/etools/constr uction/shp rogram.html. [Accessed: 01.05.2018].

Pellicer, E., Carvajal, G. I., Rubio, M. C., \& Catalá, J. (2014). A method to estimate occupational health and safety costs in construction projects. KSCE Journal of Civil Engineering, 18(7), 1955-1965. https://doi.org/10.1007/s12205-014-05912

Pillay, K., \& Haupt, T. (2008). the Cost of Construction Accidents : an Exploratory Study. 14th International Conference on Evolution and Directions in Construction Safety and Health, 456-464.

Safe Work Australia. (2015). The Cost of Workrelated Injury and Illness for Australian Employers, Workers and the Community:
2012-2013. Australia.

S. D. Choi, A Survey of the Safety Roles and Costs of Injuries in the Roofing Contracting Industry, Journal of Safety, Health and Environmental Research, Vol. 3 , no. 1, pp. 1-20, (2006).

Sha, K. (2011). Vertical governance of construction projects: an information cost perspective.

https://doi.org/10.1080/01446193.2011.63 7939

Shiferaw, A.S., Klakegg, O.J. and Haavaldsen, T. (2012). Governance of Public Investment Projects in Ethiopia. Project Management Journal, 43(4), 52-69. https://doi.org/10.1002/pmj

Siegel, J. G., \& Shim, J. K. (2000). Accounting Handbook (Third Ed.). Barron`s Educational Series.

Tang, S. L. (1997). Financial and Social Costs of Construction Accidents, 213-222.

Teo, E. A. L., \& Feng, Y. (2011). Costs of construction accidents to Singapore contractors. International Journal of Construction Management, 11(3), 79-92. https://doi.org/10.1080/15623599.2011.10 773174

Thaler, R., \& Rosen, S. (1975). The value of saving a life: evidence from the labor market. New York: Columbia University Press.

Workplace Safety and Health Institute. (2013). Economic Cost of Work-related Injuries and Ill-health in Singapore. Singapore.

Yong, H. K. (2017). Infrastructure Financing in Malaysia. Nomura Journal of Asian Capital Markets, 1(2), 26-30. Retrieved from

http://www.nomurafoundation.or.jp/en/w ordpress/wpcontent/uploads/2017/04/NJA CM1-1SP17-06.pdf 